\title{
PRISPEVEK K ODNOSOM JACOBUSA GALLUSA HANDLA DO PRAGE
}

\author{
Jitka Sn ížková (Praga)
}

Češka kultura je pokazala za osebnost Jacobusa Gallusa (Handla) živo zanimanje že $\mathrm{v}$ času njegovega delovanja na Češkem. Ljubezen in občudovanje mu izreka češki humanistični pesnik v latinščini Jurij Carolides iz Karlsperka (1569-1612) ${ }^{1} \mathrm{v}$ uvodni pesmi »Ad cantorem modularom Handelii«, natisnjeni $\mathrm{v}$ zbirki Moralia (Norimbergae 1596).

Zapuščina J. Gallusa je popisana v češčini, ${ }^{2}$ bila pa je spisana $\mathrm{v}$ sredo ob vigiliji sv. Jakoba (1591).

$\mathrm{Ta}, \mathrm{v}$ češčini spisani pregled zapuščine potemtakem sklepa Gallusovo delovanje v Pragi.

O zelo zgodnjih, doslej še neovrednotenih odnosih Jacobusa Gallusa do čeških dežel prav posebno govori rokopis peteroglasnega Officium super Levavi oculus meos, ki ga najdemo v Gradualu latino-bohemicum iz leta 1578. Do nedavnega je bila znana samo signatura univerzitetne knjižnice v Pragi UK B $1,{ }^{3}$ ki je ohranila štiri knjige - zvezke glasov. (discantus, altus, tenor, bassus). Niso pa bili popolni, zakaj manjkal je peti glas.

Fragment treh glasov, torej tri knjige iz te signature, so bile že prej znane glasbenim zgodovinarjem. ${ }^{4}$

Glasbeni zgodovinarji ${ }^{5}$ se ujemajo $\mathrm{v}$ tem, da takrat znani fragment treh glasov tega Gallusovega oficija prinaša eno izmed prvih del mladega skladatelja. »Die Musik in Geschichte und Gegenwart« pozna štiriglasni praški rokopis. ${ }^{6}$

1 Československý hudební slovník, Praga 1963, str. 552. - A. Truhlář ,Rukovět' k pisemnictví humanistickému, Praga 1908, str. 272, 305.

${ }^{2}$ Kniha inventařu (ab Anno Millesimo Quingentesimo Octogesimo Quarto et Sequentibus, Arhiv mesta Prage, sign. 1173, fol. $217 \mathrm{~b}-218$ a.

3 J. Truhlář, Catalogus Codicum Manu Scriptorum Latinorum qui in C. R. Bibliotheca Publica atque Universitatis Pragensis Asservatur. Tom II, Prague 1966, str. 126-127.

4 J. Mantuani, predgovor k izdaji motetov Jacobusa Gallusa, DTOe, Wien 1899, zv. VI, str. XVI.

5 K. Konrád, Dějiny posvátného zpěvu staročeského. Praga, 1893, str. 247. J. Racek, Česká hudba, Praga 1958, str.79. - Československý hudební slovník, Praga 1963, str. 360.

${ }^{6}$ MGG IV, 1332. 
Gallusovo avtorstvo je $\mathrm{v}$ tej signaturi zapisano $\mathrm{v}$ diskantovem zvezku po introitu Rorate coeli pred Kyrie na fol. $328 \mathrm{a}$, kjer je navadeno $\mathrm{z}$ drobnim zapisom $\mathrm{z}$ istim črnilom celotno ime Jacobus Handl (signatura UK XIX B 1a [diskant], fol. 328 a).

Dopolnilni glas $\mathrm{k}$ tej signaturi je strahovska knjiga $\mathrm{z}$ glasom »vagans«, sign. D A II $3 .^{7}$

Pri spartiranju sem dognala, da gre za peti glas, ki sodi $\mathrm{v}$ vseh zapisanih oficijih $v$ družino štirih doslej znanih glasov in da imamo potemtakem $v$ tem viru (Graduale latino-bohemicum) na voljo celo vrsto glasovno kompletnih mašnih oficijev pretežno češkega izvora in utrakvističnega značaja, kakor ga določa že sama vsebina ( $\mathrm{z}$ oficijem o Janu Husu), prav tako pa tudi oblika oficijev $^{8}$ in uvodno besedilo. Gallusova peteroglasna maša je tu uvrščena med druge mašne oficije čeških avtorjev Jiřija Rychnovskega, Jana Trajána Turnovskega, Simonida Montana in Mathea Pořičenskega.

Potemtakem navedeno še bolj bogati seznam del Jacobusa Gallusa in ta dognanja so tem dragocenejša, ker gre za zgodnja dela skladatelja. Glasovno tvorijo kompletno celoto. $\mathrm{S}$ transkripcijo in spartacijo dobivamo partituro zelo učinkovitega in kar dragocenega umetniškega dela.

Ves oficij uvaja $\mathrm{v}$ tenorskem zvezku, prav kakor ostala dela tega rokopisa, iluminirana stran (fol. 327 a) s tekstom, ki nam posreduje natančno datacijo tega dela: »Officium Sacrum de Annunciacione Beatae Mariae Adam Rossa pro decore Christi Sumptu privato curavit Anno Virginei partus 1578.«

Nato se vrstijo naslednji deli: Rorate coeli, Kyrie, Gloria, motet Laus tibi Christe (pars II: Prophaetae Sancti), Mittit ad virginem, Patrem (Credo), motet Beata es virgo Maria (pars II: Ave Maria).

Kyrie Gallusove maše se začenja na naslednjih straneh glasovnih knjig:

discantus: sign. XI B 1 a, fol. 328 a, Univ. knjižnica, altus: sign. XI B $1 \mathrm{~b}$, fol. $333 \mathrm{~b}$, Univ. knjižnica, tenor: sign. XI B 1 c, fol. 329 a, Univ. knjižnica, vagans: sign. D A II. 3, fol. 295 a, Strahov, Pamatnik pisemnictví, bassus: sign. XI B $1 \mathrm{~d}$, fol. 315 a ... Univ. knjižnica.

Pri spartaciji tega dela se lahko zamislimo $\mathrm{v}$ celo vrsto zanimivosti: 1. Navedeni so trije stalni deli maše: Kyrie, Gloria, Credo. Manjkajo potemtakem Sanctus, Benedictus in Agnus. To dejstvo nas ne preseneča, zakaj utrakvisti so namenoma izpuščali Angus, in to iz notranjega teološkega vzroka.$^{9}$ Marsikje so izpustili Sanctus in Benedictus tudi tedaj, če so vpisovali v svoje rokopise maše katoliških avtorjev. ${ }^{10}$ Zato pa najdemo tu organske

7 K. v. Fischer, Repertorium der Quellen tschechischer Mehrstimmigkeit des 14. bis 16. Jahrhunderts, in Essays in Musicology in honor of Dragan Plamenac, Pittsburgh 1969, str. 51.

8 J.Snížková. Le motet tchèque v publ. »Musica antiqua«, Bydgoszcz 1969, str. 35 .

9 F. Hrejsa, Agenda novokaličnická, Časopis Českého musea, 1918, str. 61. J. Snížková, Češti kontrapunktikové druhé poloviny 16. stoleti (v tisku). str. 28

E. Trolda, Česká mešní komposice v dobe rudolfinské, Praga, Cyrill 1933, 
vključitve spremenljivih stavkov v podobi motetov. (Laus tibi Christe, Mittit ad virginem, Beata es virgo Maria).

2. Graduale latino-bohemicum se je ujemal s petimi zvezki, ki so danes vsi dostopni $\mathrm{v}$ univerzitetni knjižnici in na Strahovu. J. Mantuani je poznal tri zvezke te signature iz univerzitetne knjižnice; vedel je, da gre za glasovni odlomek, in je domneval, da je prvotna zbirka vseh glasovnih knjig tega graduala pripadala Janu Trajánu Turnovskemu.11

Ta češki polifonik je bil utrakvist, deloval je kot župnik v Sepekovu in $\mathrm{v}$ Netvořiju. Kot skladatelj je prav tako avtor peteroglasnih motetov in oficijev, pisal pa je tudi kantofirmalne, pretežno štiriglasne strofične duhovne pesmi. $^{12}$

Jan Traján Turnovský ni bil ne lastnik in ne urednik vsebine teh glasovnih knjig, ki so bile spisane za svetomihaelske literate $\mathrm{v}$ praškem Novem mestu, o čemer nas poučuje uvodno besedilo rokopisa. Turnovský je bil avtor dveh signiranih oficijev $\mathrm{v}$ rokopisu (Officium super Dunaj voda hluboká in Officium super Hierusalem, Hierusalem). Tudi v uvodnem besedilu rokopisa, $\mathrm{v}$ zvezku za tenor, je naveden poleg dveh nadaljnjih imen čeških kontrapunktikov: slavnega Jiřija Rychnovskega in manj znanega Mathea Iuniora Pořičenskega.

Ni nam znano, v kakšnem odnosu je bil Jacobus Gallus do Jana Trajána Turnovskega ali do drugih dveh čeških utrakvističnih skladateljev. Odnos naših avtorjev in Jacobusa Gallusa do svetomihaelskega bratstva je bil enak -vsi so tu navedeni kot skladatelji in položaj Jana Trajána Turnovskega glede na ta rokopis nikakor ni bil privilegiran.

3. Zastavlja se torej vprašanje, ali je bila Gallusova skladba napisana za Prago, ali pa so si svetomihaelci samo prepisali to mašo v svoj rokopis, pač po lastnih potrebah. Vsi oficiji tega rokopisa imajo po obliki novoutrakvistični značaj. Utrakvistični značaj tega rokopisa poudarja tudi peteroglasni oficij o čeških mučencih - Janu Husu in Jeronimu. (Officium super Vias tuas Domine demonstra mihi. ${ }^{13}$ Avtor te anonimne maše je verjetno Jiři Richnovský.

4. Pozornost vzbuja še dejstvo, da ima Gallusova maša enako nizko lego vseh glasov kakor drugi zbori, ki so jih peli moški glasovi, kar je za češko polifonijo dovolj značilno. ${ }^{14}$

Gallusova skladba respektira zgradbo novoutrakvističnega oficija in njegovo razsežnost. Tekstne spremembe $\mathrm{v}$ stalnih delih, posebej še v Credu, so za utrakviste karakteristične. Tudi $v$ Gallusovi maši najdemo npr. frazo Genitum non factum est.

Glede na to, da ni ta Gallusova maša ohranjena nikjer drugod kot samo v praškem viru, se zdi verjetno, da jo je bil Gallus napisal za svetomihaelsko literatsko bratstvo.

\footnotetext{
${ }_{11}$ DTOe VI, str. XVI.

12 Československý hudební slovník, Praga 1965, str. 793-794; MGG XIII, $619-620$.

13 J. Snížková, Česká polyfoní tvorba, Musica polyphonica Bohemiae, Praga 1958, ilustr. priloga 1. Ista: Česká vokalní polyfonie (Sborový repertoir), Praga 1969. Introit a Kyrie, str. $7-21$, Prosa str. 22-26.

${ }^{14}$ E. Trolda, Česká mešní komposice v době rudolfinské, Cyrill, Praga 1933, 31.
} 
Cerkev sv. Mihaela v praškem Novem mestu (sedaj cerkev v Jirhařicah) je dobila na svoj prvotni romanski temelj gotično prestavbo okrog leta 1348, v dobi Karla IV. Leta 1511 pa so ji dali poznogotski mrežasti svod. ${ }^{15} \mathrm{~V}$ času, ko je okrog leta 1577-1578 nastal naš rokopis, je bila cerkev v posesti novih utrakvistov, pozneje pa so rokopis prevzeli evangeličani in luteranci. ${ }^{16}$ Svetomihaelsko bratstvo literatov je očitno imelo visoko raven, ${ }^{17}$ zakaj že ta pet zvezkov obsegajoči repertoar je bil zelo zahteven.

5. Zgradba celotnega oficija je izrazita. Deli se na stalne in spremenljive dele. a) Stalni deli so $\mathrm{v}$ tonalnem sorazmerju. Kyrie in Gloria sta $\mathrm{v}$ frigijski tonaliteti. Credo se začenja eolsko, toda $\mathrm{v}$ zadnjem sklepu prehaja $\mathrm{v}$ frigijsko tonaliteto, kar je dano $\mathrm{z}$ modelom, ki je $\mathrm{v}$ Credu intervalno obrnjen. Cantus firmus $\mathrm{v}$ tenorju je podan $\mathrm{v}$ dolgih notah in se potemtakem razločuje od melodike drugih glasov; v Credu pa ima tenor enake vrednosti kakor drugi glasovi, tako da se ne razločuje. Jedro vseh stalnih delov je monotematično. b) Med Glorio in Credo sta vložena dva moteta kot spremenljiva dela (dvodelen Laus tibi Christe, sedmerodelen Mittit ad virginem). Načelno nista v tematičnem razmerju do stalnih delov. Sicer imata oba oznako -b-, vendar nista medsebojno združena s tehniko modelov in ne s kontrapunktično tehniko.

Motet Laus tibi Christe obdeluje koral v tenorju s frigijskim sklepom. Ne uporablja imitacijske tehnike, njegova sestava je kantofirmalna.

Motet Mittit ad virginem sestoji tekstno in glasbeno iz naslednjih delov:

I. Mittit ad virginem (discant: Charitas insignit ...)

II. Naturam superat (disc.: Mirificares ...)

III. Exi qui mitteris (disc.: O vere Sancta)

IV. Accede nunctia (disc.: Celsus nunctiat)

V. Audit et suscipit (disc.: O Maria gratiosa)

VI. Qui nobis tribuat (disc.: Ave sponsa)

VII. Amen.

$\mathrm{Z}$ nastopom drugega teksta $\mathrm{v}$ diskantu, česar pa ni na začetku posameznih delov, temveč po prvi kontrapunktični fazi, prihaja tudi drugačna melodična kantilena $v$ diskantu in ta ni istovetna $s$ cantusom firmusom. Kantilene $\mathrm{v}$ diskantu so prastare; iz izrazito češkega materiala je znana melodika iz drugega dela $\mathrm{v}$ diskantu »Mirificares et nova atone mandita «, to pa $\mathrm{v}$ svojem melodičnem obrisu, kakor ga najdemo v Harmoniae univocae Matouša Kolina iz Choterine, ${ }^{18} \mathrm{ki}$ so bile natisnjene leta 1555 . Tam je ta melodija, narejena na tekst Puer olim senio eneratus, označena kot češka melodija. Kontrapunktična tehnika $\mathrm{v}$ motetu Mittit ad virginem kaže starejše poteze kot polifonija stalnih mašnih delov. Vsi sklepi so - razen ene same izjeme plagalni.

15 E. Poche, Praha krok za krokem, Praga 1948, 142.

16 F. Fischer, Faráři podoboji v Praze 1609-1620, Časopis přátel starožitností XLVII, Praga 1939, 20-25.

17 K. Konrád, Dějiny posvátného zpěvu staročeského, Praga 1893, 273.

18 J. Pohanka, Dějiny české hudby v přikladech, Praga 1958, 63. Československý hudební slovník, Praga 1963, 695-696. 
c) Sklep celotnega oficija tvori motet Beata es virgo Maria; ta je dvodelen $\mathrm{z}$ drugim delom Ave Maria. Ni pa edini v doslej znanih motetih Jacobusa Gallusa s to tematiko. ${ }^{19}$

Gallusov šesteroglasen motet Beata es virgo Maria je skladen v tekstu prvega dela, tudi nastop prvih štirih not je tak, vendar je motet glasbeno povsem drugačen. Tudi peteroglasni motet Beata es virgo ${ }^{20}$ je glasbeno in glede na model tudi po kontrapunktičnem delu povsem drugačen. Gallusov kompozicijski rokopis je $\mathrm{v}$ tem delu dokaj opazljiv: kontrapunkt je zgrajen na imitaciji in mejni glasovi so $\mathrm{v}$ kvintnem razmerju do drugih glasov, torej tudi do tenorja in do osnovne miksolidijske tonalitete. Ta tehnika ga veže z Gallusovimi stalnimi mašnimi deli. S svojim naznačevanjem -b- pa spet navezuje na predhodne, spremenljive dele. $\mathrm{S}$ svojim razmeroma daljšim obsegom, $\mathrm{z}$ dvodelnostjo in enako se ponavljajočim sklepom $\mathrm{v}$ obeh delih ter s celotno proporcijo ustreza ta motet običajni gradnji čeških utrakvističnih oficijev, ki so imeli v sklepnem delu dolg motet in prav to je nadomeščalo glasbeno opuščeni Agnus, morebiti tudi Benedictus in Sanctus. Oba dela moteta sta zaključena plagalno. Formalno bi mogli oba dela notranje razdeliti na dva odstavka, torej $\mathrm{z}$ naslednjo strukturo:

Pars I:

miksolidijska A brez sklepa

B plagalni miksolidijski sklep

(Beata es virgo...)

(Genuisti qui te...)

Pars II:

jonska $\mathrm{C}$ brez sklepa

(Ave Maria, gratia plena....)

B plagalni miksolidijski sklep

(Genuisti qui te...)

Tako formalno zgradbo najdemo $v$ celi vrsti motetov, npr. v delu Jacobusa Vaeta $^{21}$ in še $\mathrm{v}$ mnogih čeških motetih. Po tekstni vsebini je snov moteta kratka, ${ }^{22} \mathrm{~s}$ čimer pa jasneje ne določa ničesar drugega.

6. Na vprašanje, če je Gallus avtor celotnega oficija $z$ introitom, $z$ dvema notranjima in enim sklepnim motetom, ali pa je tudi avtor stalnih mašnih delov, ne moremo trenutno odgovoriti.

Nesporno je Gallus avtor treh stalnih delov, ki so monotematični in izdelani z enako izčiščeno imitacijsko tehniko. Avtorstvo je priznano z njegovim imenom, ki ga najdemo po introitu Rorate coeli pred Kyriem. Tudi motet Beata es virgo Maria je izdelan na enak kontrapunktičen način.

$\mathrm{Za}$ Gallusovo avtorstvo tudi $\mathrm{v}$ drugih delih oficija govorijo vzajemno zakonita arhitektura, enako zgrajeni sklepi in tonalni odnosi motetskih delov.

Zoper Gallusovo avtorstvo $v$ motetih Laus tibi Christe in Mittit ad virginem pričajo naslednji razlogi: a) Drugačna kantofirmalna tehnika, ki predstavlja starejši nizozemski tip, vštevši tudi plagalne sklepe in pomanjkanje kromatike. b) Motet Laus tibi Christe se $\mathrm{v}$ besedilu naravnost dotika literatov

19 DTOe 1917, XXXVIII, str. 146.

20 DTOe, XXVI, B 51/52, str. 66.

21 M. Steinhardt, Jacobus Vaet and his motets, Michigan 1951, 29.

${ }^{22}$ DTOe XXVI, 251. 
(literatorum turba...), glasbeno in kontrapunktično pa je blizu motetom Jana Trajána Turnovskega. Motet Mittit ad virginem uvaja $\mathrm{v}$ diskant druge, na Češkem priljubljene melodije. c) Graduale latino-bohemicum je izrazito novoutrakvističen. Jacobus Gallus je bil prepričan katoličan ${ }^{23}$ in je pisal maše na podlagi vatikanskega ordinarija.

Kajpada, nikjer nimamo prepričljivega dokaza o tem, da bi Gallus ne bil avtor teh spremenljivih stavkov - motetov in šele nadaljnje preučevanje celotnega praškega vira bo moglo jasno osvetliti zastavljeno vprašanje. Uvrstitev dela Jacobusa Gallusa v češki rokopis pa dokazuje veliko priljubljenost tega avtorja $\mathrm{v}$ Pragi in sicer že leta 1578, torej še v mladostni dobi skladatelja. Repertoar svetomihaelskega bratstva literatov je potemtakem uvrstil v svoje rokopisne knjige glasov eno izmed najstarejših Gallusovih maš.

Nadaljnji, doslej še nekomentirani dokument o Gallusovem odnosu do češke polifonije, je fragment dveh glasov moteta Není v síle lidu (Ni v močeh ljudstva) iz dveh glasovnih knjig št. $75-76 \mathrm{v}$ Klatovih. Jacobus Gallus je naveden $\mathrm{v}$ knjigi bassus, in sicer $\mathrm{v}$ indeksu vseh skladb in avtorjev, ki jih obsega rokopis. Motet je tu naveden kot št. 42 .

Pred zapisom notacije ne najdemo ne avtorske označbe Gallusa ne nobene druge opombe. Tenor fol. $170 \mathrm{~b}-171 \mathrm{a}$, bassus $156 \mathrm{~b}-157 \mathrm{~b}$. Motet ima dva dela:

I. pars: Není $\mathrm{v}$ síle lidu ani $\mathrm{v}$ počtu lidu ( $\mathrm{Ni} \mathrm{v}$ močeh ljudstva in ne $\mathrm{v}$ njegovem številu).

II. pars: O Bože náš, Stvořiteli náš, Vykupiteli (O naš Bog, naš Stvarnik, Odrešenik).

Pri tej skladbi ni niti $\mathrm{v}$ indeksu predpisano število glasov, toda omenjeni knjigi sta ostanek glasovne družine šestero do osmeroglasnih zborov. Naš motet ima oznako -b-, tonaliteta pa utegne biti F-dur. Melodika tu ohranjenih glasov je $\mathrm{v}$ zvezi $\mathrm{z}$ deklamacijo čeških besed in je zlasti $\mathrm{v}$ drugi polovici moteta zelo recitativna.

Klatovske glasovne knjige so bile spisane v zadnjem petnajstletju 16. stoletja in vsebujejo pretežno osmeroglasne oficije in motete. Izmed avtorjev je $\mathrm{v}$ njih najbolj zastopan češki polifonik Pavel Spongopeus Jistebnický. Vrsta skladb je datirana $v$ obdobju 1585-1594-1596.

Glede na to, da ima motet Není v síle lidu ohranjena samo dva glasova, danes še ni mogoče odgovoriti na bistveni vprašanji:

1. Ali je Jacobus Gallus pisal ta motet na češki tekst ali pa gre za prevod njegovega moteta $\mathrm{v}$ češčino?

2. Ali je spisal ta motet češki avtor po Gallusovem modelu? Potemtakem bi šlo za parodičen motet, kakršni sicer v tem času in v ostali glasbi niso bili pogosti, vendar so se le pojavljali.

$\mathrm{V}$ tem vprašanju je dokaj pomembno dejstvo soseščine tega moteta $\mathrm{v}$ klatovskih rokopisnih knjigah. Pod št. 41 je tu naveden motet Pavla Spongopea Jistebnickega Christianum plebs (II. pars: Avertatur furor...), ki opeva v

23 R. Petschek-Kafka, Bohemia, v publ. G. Reese, Music in the Renaissance, New York, 1952, 736; MGG IV, 1329-1334. 
ponavljajočem se sklepnem delu cesarja Rudolfa II. (. . . et exaudi Rudolphum Caesarem atque regem et populum tuum cum laetitia).

Kot št. 43, torej za našim motetom, je spet skladba Pavla Spongopea, in sicer Officium super Praeter rerum seriem Josquini iz leta 1594, očitno torej periodična maša po Josquinovem modelu.

Potemtakem ni izključeno, da je tudi naš motet Není v síle lidu prišel izpod peresa Pavla Spongopea Jistebnickega, in to po modelu Jacobusa Gallusa Preseneča nas samo, da tenorski glas, ki bi bil moral izrazito citirati model, nastopa sočasno $\mathrm{z}$ basom, ni pa imitiran, ampak je le dostavek basovemu fundamentu. Očitno je, da to ni bilo izdelano s tehniko kontrapunktične imitacije in tudi ne s starejšo kantofirmalno tehniko, saj je skladba najbrž imela osmeroglasovno koncepcijo, izdelano morebiti tudi dvozborno s posrečenim harmonskim zvokom. Na podlagi drugih fragmentov posameznih glasov Pavla Spongopea ${ }^{24}$ vemo, da je ta češki skladatelj uporabljal tehniko beneškega večzborja in bi ne bila izključena neka zveza z Jacobusom Gallusom. Tudi ta klatovski vir z dvema glasovnima knjigama kaže utrakvističen tip, četudi je skoraj dvajset let mlajši od praškega Graduale latino-hohemicum. Ne uvaja namreč samo del, ki so izoblikovana po vzorcih novoutrakvistov, pretežno mašne oficije, temveč najdemo tam tudi vrsto čeških utrakvistično usmerjenih skladateljev. (Pavel Spongopeus Jistebnický, Jan Simonides Montanus, Ondřej Chrysoponos Jevičský, Šimon Bar Jona Opolský - Šlezijec, ki je deloval v Plznju.)

V vsakem primeru prispeva navajanje imena Jacobusa Gallusa ob češkem motetu Není v síle lidu k spoznanju, kakšen je bil odnos tega avtorja do češke polifonije.

Glasovno kompleten Gallusov Officium super Levavi oculos meos iz praškega rokopisa Graduale latino - bohemicum je močan dokaz vzajemnih odnosov skladatelja $s$ češko polifonijo omenjenega obdobja.

\section{SUMMARY}

One of Jacobus Gallus Handl's early compostions - the »quinque vocum officium super Levavi oculos meos" - has recently been found in its complete version in the graduale latino-bohemicum; its four voices sign. UK XI B $1 \mathrm{a}, \mathrm{b}, \mathrm{c}, \mathrm{d}$ are completed by a fifth voice vagans from Strahov sign. D A II 3. - The threevoice fragment was known before in literature.

The officium is signed with the name of Jacobus Handl written in full, after the introitus Rorate before Kyrie in the part-book discant (fol. 328 a). In the tenor part-book it is introduced on fol. 327 a by the introductory text »Officium Sacrum de Annunciacione Beatae Mariae Adam Rossa pro decore Christi Sumptu privato curavit Anno Virginei partus 1578 «. This is followed by Rorate coeli, Kyrie, Gloria, Laus tibi Christe, Mittit ad virginem, Patrem (Credo), Beata es virgo Maria.

When examining the scores we notice a series of interesting features:

1) The officium has a pronounced neo-calixtine structure. It introduces several motets, it omits Sanctus, Benedictus, Agnus from the fixed parts of the mass, it

24 Československý hudební slovník, Praga 1965, 581; Snižková, Pavel Spongopeus Jistebnický - mistr známý i neznámý, Betramka, věstník Mozartovy obce v ČSSR. Praga 1969. 
ends with a two-part motet and there are slight changes in the text of the ordinarium.

2) The manuscript of the graduale latino-bohemicum was made for the literary fraternity of St. Michael's church in the New Town of Prague. The Czech composer Jan Traján Turnovský is one of the authors of the mass officia represented in this manuscript. He was, however, neither the owner nor the editor of the part-books.

3) The graduale is pronouncedly neo-calixtine, which is evident from the contents as well as the form of the mass officia, from the introductory Latin text and last but not least from the introduction of the officium concerning the Czech martyrs Jan Hus and Jeroným (officium super Vias tuas Domine demonstra mihi) whose author is probably Jiři Rychnovský.

4) The compact structure with inserted motets and the original low range typical for St. Michael's Church and the calixtine fraternities hint at the strong probability that Gallus wrote this composition for St. Michael's Church in Prague. The composition is dated 1578 .

5) The analysis of the work raises the question whether Gallus is the author of the entire composition or only of the fixed parts.

Gallus' authorship of the whole composition is sustained by the integrity of the architectonic plan with monothematic fixed parts and the rather archaic variable movements with a systematic regularity in conclusions and keys. Beyond any doubt Gallus is the author of the mentioned fixed parts Kyrie, Gloria, Credo, which are monothematic.

Gallus' autorship of only the fixed and not the variable parts can be supported by the following facts:

a) A different counterpoint technique, an older type, including plagal conclusions, a lack of chromatic art in the free parts (Laus tibi, Mittit ad virginem).

b) The motet Laus tibi is, in its composition, similar to motets by J. Traján Turnovský.

c) The officium with variable movements can frequently be found among Calixtines, while Jacobus Gallus was Catholic by upbringing and conviction.

Another, in literature as yet unmentioned, document of Jacobus Gallus' relationship to Czech polyphony is the two-voice fragment of the motet »Není v síle lidu« (It is not in the power of the people) in the part-books No.75-76 in Klatovy, where it is mentioned in the index of compositions and authors in the book bassus, as number 42 .

The part-books of Klatovy date from the last 15 years of the $16^{\text {th }}$ century and include works by Czech composers, such as Pavel Spongopeus Jistebnický whose compositions are dated between the years 1585-1596. They are neo-calixtine. Due to the fragmentary nature of the two voices from compositions originally sexvocum or octovocum, we are as yet unable to answer the following questions:

1) Whether Gallus wrote this motet on basis of a Czech text or of a translation.

2) Whether this motet was written by a Czech composer (probably P. Spongopeus) according to Gallus' model in the same way as the adjoining composition No. 43 »officium super Praeter rerum Josquini«.

In the inventory of music books by Jacobus Gallus Handl, written in the Czech languague after his death in 1591 (Archives of the city of Prague, the Book of Inventories 1584-1596 sign. 1173) no notes on these compositions can be found.

The complete voice scores of the »officium super Levavi oculos meos« by Jacobus Gallus Handl, dated 1578, from the Prague manuscript of St. Michael's literary fraternity, as well as the two voice fragment of the motet "Není v síle lidu" dating from the end of the $16^{\text {th }}$ century, are striking documents of Jacobus Gallus Handl's mutual relationship with the Czech neo-calixtine polyphony. 